\title{
HORTICULTURAL LITERATURE IN THE LIBRARIES OF A. E. SILVA TAROUCA, THE CZECHOSLOVAK DENDROLOGICAL SOCIETY, AND THE STATE AGRICULTURAL EXPERIMENTAL OBJECTS UNTIL 1936
}

\author{
Ivana Barošová1, Markéta Šantrůčková1 \\ ${ }^{1}$ The Silva Tarouca Research Institute for Landscape and Ornamental Gardening (RILOG), Květnové náměstí 391, \\ 25243 Průhonice, Czech Republic \\ Link to this article: https://doi.org/10.11118/actaun.2021.057 \\ Received: 15. 5. 2020, Accepted: 26. 11. 2021 \\ To cite this article: BAROŠOVÁ IVANA, ŠANTRŮČKOVÁ MARKÉTA. 2021. Horticultural Literature in the Libraries \\ of A. E. Silva Tarouca, the Czechoslovak Dendrological Society, and the State Agricultural Experimental Objects \\ until 1936. Acta Universitatis Agriculturae et Silviculturae Mendelianae Brunensis, 69(6): 643-653.
}

\begin{abstract}
The subject of the study was the large library of historical horticultural literature located at the Silva Tarouca Research Institute for Landscape and Ornamental Gardening. Besides the library of Earl Arnošt Emanuel Silva Tarouca, the study also included related stocks, i.e. books and periodicals purchased by the Czechoslovak Dendrological Society and the State Agricultural Experimental Objects until 1936, the year of A. E. Silva Tarouca's death and the transformation of the research institution. Of all the topics represented, most books focused on the landscape architectonic creation of gardens. Key publications of the period can be found in the field of floriculture, dendrology, and botany. Other horticultural subjects are also represented to a minor degree. The library is therefore a comprehensive aggregate of books and periodicals dealing with the creation of gardens and parks from late 1800s until 1930s.
\end{abstract}

Keywords: horticulture, old books, Průhonice, Silva Tarouca, Dendrological Society

\section{INTRODUCTION}

Chateau libraries are a treasury of knowledge in a wide range of fields. They are deposited on various premises and the largest collection of books from chateau libraries is now maintained by the National Museum. Its staff have published several papers presenting the development and contents of chateau libraries based on the families that built them (Mašek, 2003) or based on their territory (Mašek, 1991). A Tarouca library which was deposited in the family chateau in Čechy pod Kosířem was also analyzed by Mašek (2018). Several papers have dealt with horticultural literature in chateau libraries. Here we can trace two different approaches. The older one focused on attractive titles, especially period price lists and iconography, monitoring their presence in various chateau libraries (Antonín, 1997, 1999). The other approach focuses on a selected chateau library and evaluates all the horticultural literature contained in it (Ševčíková, 2018; Pražmová, 2010). Attempts at tracing the effects of important horticultural writings on the owners and builders of landscape parks have been made by Ševčíková (2018) for the Vlašim park and Pincová (2005) for the Průhonice park.

In the first decades of the $20^{\text {th }}$ century, a comprehensive and thematically very diverse library was found in the Průhonice chateau, which was put together by Earl Arnošt Emanuel Silva Tarouca (1860-1936) and which was fully deposited 
there until 1927 when the Průhonice estate was sold to the Czechoslovak state. After this date, a part of it containing also the old books of the original Nostitz library was transferred by E. A. Silva Tarouca's daughter Marie Adelheid (1886-1945), married Beaufort-Spontin, to the Bečov nad Teplou chateau (Mašek, 2018). The Bečov library was thereby enriched by estimated hundreds of books dealing mainly with church literature and belles-lettres. The philosophical literature from the Průhonice library was probably obtained by A. E. Silva Tarouca's son Amadeus who was a professor of philosophy in Graz (Mašek, 1993). However, literature related to the creation of gardens and parks, agriculture, botany and forestry remained in the Průhonice chateau. These were the books dealing with A. E. Silva Tarouca's favorite hobbies.

The year 1922 marks the beginning of the library of the Czechoslovak Dendrological Society which was founded by A. E. Silva Tarouca in Průhonice and which was a successor to the previous one he had founded in Vienna, the AustroHungarian Dendrological Society. The Czechoslovak Dendrological Society ceased to exist in 1954 and probably after that its library was merged with the library of the Research Institute for Ornamental Gardening which was a successor organization to the State Agricultural Experimental Objects.

After the Průhonice estate was sold to Czechoslovakia, a research institute called the State Agricultural Experimental Objects was founded which was to continue the horticultural research and experiments of A. E. Silva Tarouca. The State Agricultural Experimental Objects were located in the Průhonice chateau and owned a library which was established in 1927. In 1936, Arnošt Emanuel Silva Tarouca passed away and in the same year the State Agricultural Experimental Objects were reorganized. When disposing of A. E. Silva Tarouca's inheritance, his daughters Gisela and Eleonora showed no interest in the horticultural literature, and therefore, the books remained in the Průhonice chateau and were included into the library of the State Agricultural Experimental Objects (Mareček, 2018).

The aim of this study was to describe this valuable stock of horticultural literature which was gradually built from the end of the $19^{\text {th }}$ century until 1930s, thereby capturing the historical development of the field of landscape architecture. Furthermore, the aim was to resolve which books had been bought by A. E. Silva Tarouca that may have had an influence on his creations in the Průhonice park, and which books were preferred in the creation and completion of the stocks of private as well as public horticultural institutions, i.e. the Czechoslovak Dendrological Society and the State Agricultural Experimental Objects. Last but not least, we would like to inform scientific community about this specific and interesting books collection that could be used for further studying history of garden architecture, horticulture and dendrology in the central European context.

\section{MATERIALS AND METHODS}

The study involved the stock of the library of the Research Institute for Landscape and Ornamental Gardening, where the books coming from the Nostitz family, Earl A. E. Silva Tarouca, the Czechoslovak Dendrological Society, the State Agricultural Experimental Objects, and the State Experimental Orchard in Průhonice were transferred over the course of the $20^{\text {th }}$ century. Volumes that are found here were unequivocally identifiable based on the stamps, signatures, and initials of the above mentioned persons and institutions. For the purposes of the study, books were selected that had been obtained until 1936, i.e. until the year of A. E. Silva Tarouca's death and the year the State Agricultural Experimental Objects were reorganized into the State Research Horticultural Institutes in Průhonice (Mareček, 2018). By physically checking the current library stock (approximately 20,000 book units), a total of 619 relevant items were identified including almanacs, periodicals, etc. Books that had been published before 1936 but were purchased only later by the library of the Research Institute for Landscape and Ornamental Gardening, were identified based on the accession catalogue and excluded from subsequent evaluation. Considering the absence of a record of the book's origin in the electronic form, all copies were checked and their citations and origins were recorded in a database in the Excel program.

For further evaluation, the books were classified thematically into 12 sectors:

- botany (books focusing on the natural vegetation of herbaceous and woody plants including mountainous regions, and on general knowledge of botany);

- dendrology (books focusing exclusively on woody plants, both native and exotic, and their cultivation);

- floriculture (books focusing exclusively on cultivation of perennials, bulbous plants, tuberous plants, and interior plants);

- rock gardens and rock plants (books focusing on creation of rock gardens and dealing with the assortment of rock plants for use in the garden);

- garden creation (i.e. books focusing on artistic styles or foreign inspirations from exotic gardens as well as practical books dealing with the manner of founding individual garden parts);

- special horticultural technologies (books specializing in breeding, propagation, fertilization, seed collection, etc.);

- forestry (these were predominantly manuals on establishing a forest and on forests in general);

- pomology (books focusing on growing fruit woody plants); 
- agriculture (books describing agricultural technologies);

- price lists and catalogues (these were mainly offers of foreign nurseries or their almanacs);

- periodicals (regularly published journals and almanacs of botanical gardens);

- others (unclassifiable, one-of-a-kind books defying the creation of their own category, e.g. dictionaries, castle encyclopedias, instructions for catching butterflies, etc.).

Furthermore, the books were divided according to their origin, i.e. the one who purchased the books for the library. The obtained data were evaluated and processed using the Excel program.

Besides that, a check was performed to find whether some of the books are still on the premises of the Průhonice chateau, namely in the library of the Institute of Botany of the Czech Academy of Sciences. Items were selected that might be falling into the studied field by their date and focus, however, none of the books contained the appropriate stamp or initials. It was also verified that the library of the Research Institute for Landscape and Ornamental Gardening does not contain any books of the Austro-Hungarian Dendrological Society.

\section{RESULTS}

\section{The Nostitz Family Library}

Originally, the library of earls Nostitz-Rieneck formed the foundation of A. E. Silva Tarouca's library. The Nostitz family obtained the chateau and the surrounding domain after 1800, possessing it until the marriage of A. E. Silva Tarouca to Marie Antonie Nostitz-Rieneck. After the selling of the estate in 1927, many volumes were transferred from Průhonice to the Bečov nad Teplou chateau, including some books from the original Nostitz library (Mašek, 1993). Today, only a fraction of them can be found in the library of the Research Institute for Landscape and Ornamental Gardening in Průhonice. There are 8 books marked by the Albert Graf Nostitz stamp (Fig. 1). These are some of the oldest volumes in the library; the oldest book is from 1839; it is a manual on cultivation of sugar beet and production of sugar in German language (Hlubek, 1839). Sugar beet and agricultural issues are dealt with in 7 other books that are from the

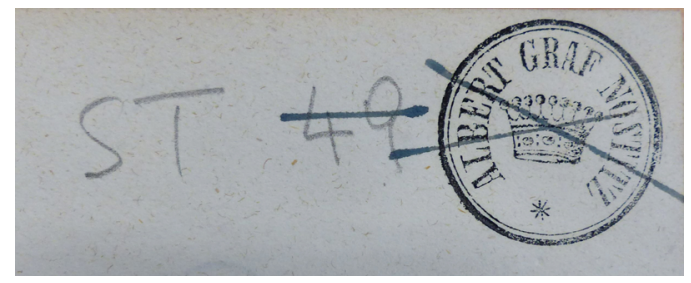

1: A photo of the crossed out Nostitz bookplate stamp period of 1840s-1850s, all written in German. Three of them were also marked by A. E. Silva Tarouca's coat of arms, others had his signature or initials added. However, none of the books focused on the field of parks and gardening.

\section{Earl A. E. Silva Tarouca's Library}

What has been preserved of A. E. Silva Tarouca's library in the library of the Research Institute for Landscape and Ornamental Gardening is the part that remained in the chateau after the reallocation of the Průhonice chateau library after the selling of the estate in 1927 and later after A. E. Silva Tarouca's death (1936). It is a thematically preserved aggregate devoted to the creation of gardens and parks, agriculture, forestry, botany and other related topics. It includes 91 items (68 books, other items are price lists and almanacs) that specify in further detail the interest, education and especially the inspiration of A. E. Silva Tarouca in creating the Průhonice park.

The books were by $80 \%$ written in German language; furthermore, there is English literature (17\%) and French literature (3\%) but no volumes written in Czech. Besides books, A. E. Silva Tarouca subscribed to almanacs of the German Dendrological Society (Mitteilungen der Deutschen Dendrologischen Gesellschaft) that appear here only after the year 1908, and to almanacs of the American Rhododendron Association from 1930s.

Only 3 books from the first half of the $19^{\text {th }}$ century can be found in the Earl's library. Other 34 books are dated between the years 1850-1899; other 30 books are dated from 1900 until 1936 (Tab. I). The oldest book is an item from 1769, a German version of L. J. M. Columell's Twelve Books on Agriculture (Columell, 1769) describing agriculture in ancient Rome, including gardens and cultivation of vegetables. The book was marked by A. E. Silva Tarouca's heraldic bookplate. Another one of the oldest works in the library is a book from 1828 written in German, describing the rock pantheon and nature reserve Malá Skála in Bohemia (Effenberger, 1828).

In total eight books were marked by A. E. Silva Tarouca's heraldic bookplate (Fig. 2). It is a yellowand-red heraldic embossed plate with the symbols of the Silva Tarouca family (Mašek, 1993). The books were further marked by A. E. Silva Tarouca's name or initials, mostly written in pencil. Later, when Silva Tarouca's library was incorporated into the library of the predecessors of the Research Institute for Landscape and Ornamental Gardening, the initials were crossed out and marked by a new serial number and the stamp of the research institute. A total of eight books with a dedication are represented among A. E. Silva Tarouca's books, two of which are from their own authors.

If we are to examine this part of the stock thematically, we mainly find a high representation of botanical publications and books focusing on the 
creation of gardens and parks (both represented by 18\%). Of the books focusing on botany, only one was marked by the Earl's bookplate, namely, a mushroom identification guide from 1874 written in German (Lenz, 1874). In 1902, A. E. Silva Tarouca's wife Marie received a dedicated book on the nature of the Riviera (Ligustica, 1898). The second book with a dedication from the botanical section is from Prof. K. Domin who gave his treatise on a phytogeographical excursion through Czechoslovakia written in German (Domin, 1928) to A. E. Silva Tarouca. An important part is comprised of a number of books on the native flora of Austria, Germany, Switzerland, Dalmatia, England and on the wild plants of America including its mountains. These volumes are mainly from the turn of the $19^{\text {th }}$ and $20^{\text {th }}$ century, i.e. the period after the Průhonice park was already established. They document the fact that A. E. Silva Tarouca's studied both botany and natural plant communities, drawing on this knowledge in his creations.

In terms of garden creations specifically, A. E. Silva Tarouca had a relatively sufficient amount books, including the fundamental Petzold's (1888) and Pückler's (1834a, 1834b) publications that influenced the Europe-wide development of landscape parks during the $19^{\text {th }}$ century. Although they were published in 1834 and 1888, A. E. Silva Tarouca probably obtained them later. He possessed the book Andeutungen über Landschaftsgärtnerei verbunden mit der Beschreibung ihrer praktischen Anwendung in Muskau by Prince Pückler-Muskau with the signature of Rudolf Lauche who worked as dendrologist and inspector in the Muskau park in the years 1891-1928. All three mentioned books contain countless handwritten notes in the text and underlined paragraphs that prove that A. E. Silva Tarouca worked with these books intensively and further drew on them. Moreover, he further elaborated on Pückler's thoughts, enhancing them with his own approach. Another book that probably became A. E. Silva Tarouca's strong inspiration and where he also highlighted paragraphs that were important to him was Schneider's book Landschaftliche Gartengestaltung (Schneider, 1907) dealing also with park creations. Camillo Schneider visited Průhonice several times, consulting the creation of the park with A. E. Silva Tarouca in person. Other interesting books in this field include the writings of Karl Foerster and Willy Lange, who wrote a personal dedication in A. E. Silva Tarouca's copy of Der Garten und seine Bepflanzung (Lange, 1913). Two books on this topic were marked with A. E. Silva Tarouca's bookplate; one was the already mentioned Petzold's Die Landschafts-Gärtnerei. Ein Handbuch für Gärtner, Architekten und Freunde der Gartenkunst (Petzold, 1888), and the other was Hermann Jäger's (1888) book devoted to the development of the art of gardening.

Among the manuals dealing in more detail with the use of particular woody plant species in parks (they occupy $12 \%$ of the library), it is certainly necessary to mention the book by H. Jäger and L. Beissner from 1889 which is also marked by a heraldic bookplate (Jäger and Beissner, 1888), on the cultivation of woody plants in regions with a similar climate to that of Germany, in which A. E. Silva Tarouca also underlined important paragraphs. Other noteworthy books containing A. E. Silva Tarouca's notes, this time without a heraldic plate, include E. Schelle's book on coniferous woody plants recommended for Central Europe from 1909 (Schelle, 1909) and an illustrated book on woody plants by J. Hartwig from 1892 (Hartwig, 1892).

If we focus on decorative flowers and bulbous plants (occupying $12 \%$ of the library), the library is completed by already the third volume by $\mathrm{H}$. Jäger, this time dedicated to flowers for the gardens, greenhouses and apartments from 1873 (Jäger, 1873), and also a supplement on new flower assortments from 1881 (Jäger, 1881). Bulbous plants and their cultivation in the garden, greenhouse and interior are the focus of a book by T. Rümpler from 1882 (Rümpler, 1882). All of the three mentioned books on flowers were marked by A. E. Silva Tarouca's name and bookplate. Other books on perennials included topics such as flower symbolism, iris monograph, spring flowers, garden carnations, flowers attractive in wintertime, annuals, or flowers for general use and those suitable for therapeutic purposes.

The mentioned manuals on woody plants and flowers, marked by heraldic bookplates, were mainly published around the end of the $19^{\text {th }}$ century and it is very likely that they were some of the first taxonomic books on which A. E. Silva Tarouca based his early creation of the Průhonice park.

To a lesser extent, the Tarouca library contains topics such as forestry (7\%), agriculture (4\%) and creation of rock gardens (3\%). Now it is necessary to mention two important books that probably influenced A. E. Silva Tarouca in his creation of an alpine garden, and which were publications of significance in their time, My Rock Garden by R. Farrer from 1908 (Farrer, 1908) and AlpenPflanzen in der Gartenkultur der Tiefländer by E. Wocke (Wocke, 1898). Both books contain A. E. Silva Tarouca's highlights of paragraphs relevant to him. At the time, these books were recognized Europe-wide.

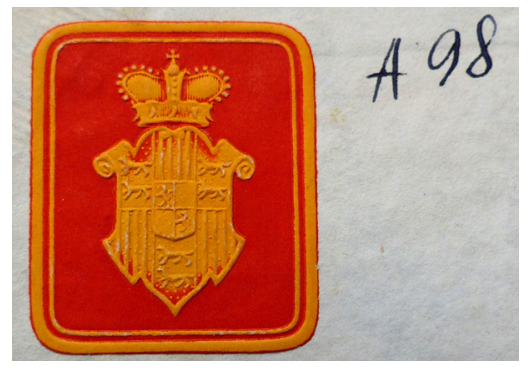

2: A. E. Silva Tarouca's heraldic bookplate 
In his library, A. E. Silva Tarouca possessed books on the whole range of park and garden creations, from the composition layout to the plant detail, such as woody, perennial, bulbous, annual and alpine plants.

\section{Library Stock of the Czechoslovak Dendrological Society}

This is the stock of the Czechoslovak Dendrological Society which A. E. Silva Tarouca presided over. The books were marked by the stamp of the Dendrological Society in Prühonice - Club Garden (Fig. 3). The Czechoslovak Dendrological Society was active from 1922 to 1954 (Barošová, Vávrová and Šantrůčková, 2010). In this study, we monitor only books obtained during A. E. Silva Tarouca's lifetime, i.e. until 1936. In total, they represent 140 items (37 books; the rest are price lists, almanacs, and periodicals).

The largest part of all 140 items in the stock is comprised of periodicals, followed by almanacs and plant catalogues of the Czechoslovak Dendrological Society as well as from abroad, e.g. catalogues of the Späth company, bulletin of the French Dendrological Society, and almanacs of the German Dendrological Society. In contrast to A. E. Silva Tarouca's library, the stock newly contains periodicals, ranging from foreign journals such as the Journal of the Arnold Arboretum Harvard University, Notes From the Royal Botanic Garden, French Revue Horticole, Möllers Deutsche Gärtner-Zeitung, Gartenschönheit, to the Czech monthly Príroda (Nature), botanical journal Preslia, the journal Vesmir (The Universe), the horticultural magazine Zahrada (The Garden) published by J. Vaněk, furthermore, České zahradnické listy, later Československé zahradnické listy (Czech/oslovak Horticultural Notes), Praktický rádce pro zahradnictví a chov drobného zvírectva (Practical Guide to Gardening and Small Animal Breeding), Naše zahrádka (Our Garden), Časopis českých zahradníkü (Czech Gardeners' Magazine).

Books obtained until 1936 are only 37. Mostly represented in the stock are books in Czech language (39\%) and in German language (32\%), there are fewer books written in English (16\%) and books in French (13\%). There are also individual publications written in Polish, Finnish, and Estonian. A substantial part of the stock contains books published only after 1900 . There is only one book of an older date, namely, a guide to collecting products of nature. Books were purchased only after the establishment of the society in 1922. Thematically, 10 books are focused on garden creations, 8 books are focused on dendrology, and 7 of them deal with floriculture. A few other pieces represent botany, forestry, and agriculture.

Valuable and seminal books include the fourvolume series of Sargent's books on the species that had been collected in China for Arnold's arboretum (Sargent 1913-1914). Furthermore, there are records written in English from the Botanical Garden in Edinburgh from 1919 to 1921 (His Majesty's Stationery Office, 1921) and from 1928 (His Majesty's Stationery Office, 1928). The book Der Königliche Botanische Garten und das Königliche Botanische Museum zu Dahlem (Ministerium der Geistlichen, Unterrichts- und Medizinal-Angelegenheiten, 1909) deals with the Botanical Garden in Berlin's Dahlem.

Also noteworthy is the book by Batěk and Kumpán on starting a garden (Batěk and Kumpán, 1922) which was published in the same year the Czechoslovak Dendrological Society was established. A. E. Silva Tarouca, C. Schneider and other collaborators of the Dendrological Society published already in the times of the AustroHungarian Dendrological Society the trilogy Pflege und Verwendung aller Bekannten in Mitteleuropa im freien kulturfähigen ausdauernden krautigen Gewächse about coniferous woods, deciduous woods and perennials that was printed five times from 1910 till 1934. Only the fourth edition of Unsere Freiland-Stauden is contained in the library stock of the Czechoslovak Dendrological Society till nowadays (Silva Tarouca, Schneider et al., 1927). Furthermore, Schneider's books Deutsche Gartengestaltung und Kunst and Landschaftliche Gartengestaltung (Schneider, 1904, 1907) are found here, focused on the art of gardening and garden creations, a monograph on dahlias by C. Schneider and K. Foerster (Foerster and Schneider, 1927), and a monograph on roses by C. Schneider and W. Mütze (Mütze and Schneider, 1924). A book by W. Lange and O. Stahn is represented by Gartengestaltung der Neuzeit (Lange and Stahn, 1919) focused on garden creations, and book on perennials written in English by G. Vos and T. W. Sanders Easilygrown Hardy Perennials (Vos and Sanders, 1902) is also worthy of attention. We find some interesting topics in the books, such as orchids for cutting, cacti cultivation, or the issue of landscape cemeteries.

Only one book is provided with notes, namely a guide to starting nature collections of insects as well as plants from 1894 written in Czech, however, the authorship of the said notes is unknown (J. Lorenz, 1894).

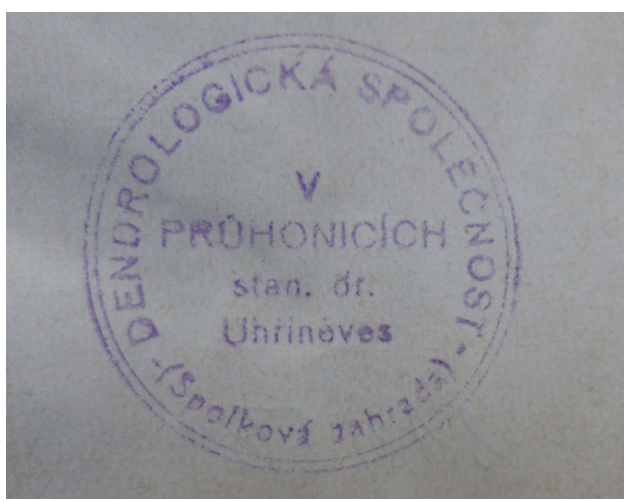

3: Stamp of the Dendrological Society in Průhonice (Club Garden) 


\section{Library of the State Agricultural Experimental Objects}

This was the youngest researched part of the library of the Research Institute for Landscape and Ornamental Gardening for which purchases were made after the selling of the Prühonice estate to the state in 1927. In the same year, a research institution was established in Průhonice, located in the chateau, named the State Agricultural Experimental Objects that had the Průhonice park and horticultural research in its care. The books were marked by the stamp of the State Agricultural Experimental Objects or the State Experimental Orchard in Průhonice which was interconnected with the experimental objects. In 1936 the research institution was renamed as State Horticultural Research Institutes, and books were marked by the new stamp, making the whole aggregate clearly identifiable. A. E. Silva Tarouca and his family were allowed to stay at the chateau until his death and to take advantage of this library stock because of his close cooperation with Associate Professor Kavka, director of the State Agricultural Experimental Objects.

In total, it contains 380 items (books, almanacs, periodicals) of which 329 books are of the State Experimental Agricultural Objects (Fig. 4) and 13 books belong to the State Experimental Orchard. It is noticeable that by the establishment of the State Experimental Objects the library was enriched by the subject of horticulture, being the most numerous part of the stock. In terms of periodicals, a large part is comprised of almanacs of the German Dendrological Society, Oslavný sborník Rakouské zahradnické společnosti (Celebrative Anthology of the Austrian Horticultural Society) 1827-1927, Phenologické ročenky československé (Czechoslovak Phenological Almanacs) from the 1930s, almanacs of the Czechoslovak Agricultural Academy from 1928, 1931, and 1934. Gardening magazines were collected including also older years, Gartenkunst from the years 1931-1936, Möllers Deutsche GärtnerZeitung from the years 1914-1918 and 1920-1939, English Gardeners' Chronicle from the year 1925 and 1926, Illustrierte Flora 1884-1887, Gartenschönheit from the years 1923-1930.

The books were mostly represented in German language (47\%), followed by Czech (30\%), English (20\%), and least of all, in French language (3\%). It is thus a collection of literature available on the European level, while books of an older date were purchased in abundance, as well. The oldest book is from 1797, a sample book of kinds of wood with a German commentary (Commission des Privilegirten Industriecomtoirs, 1797). Thirty five books were published in the second half of the $19^{\text {th }}$ century, among which there is a number of Alpine flora encyclopedias, a manual for leading paths within parks, an assortment manual for broadleaved shrubs, German dendrology by W. Lauche (Lauche, 1883), floriculture by J. W. F. Bosse
(Bosse, 1859), Vilmorin's illustrated floriculture from 1873 (Grönland, Rümpler, 1873). Almost 90\% of books, however, are dated in the first half of the $20^{\text {th }}$ century. There is a marked representation of books dated between 1922 and 1931; the largest number books are from the year 1927 (27 pieces). Besides older publications, up-to-date new releases were purchased in abundance, as well.

Thematically most represented here are publications that deal with garden creations (22\%); almost equally represented are botanical subjects (12\%), dendrology (13\%), and floriculture (12\%). To a lesser degree there are represented forestry (7\%), agriculture (6\%), and horticulture technologies $(6 \%)$, yet, the overall volume of said books is not negligible. The least percentage of books are devoted to rock and alpine plants (2\%) and pomology (1\%). A relatively large group is identified as other books (9\%) which include dictionaries, encyclopedias, lexicons of municipalities, microscopy and many others that cannot be classified among the more numerous categories. Among others, they also include Sedláček's extensive work Hrady, zámky a tvrze království Českého (Castles, Chateaux and Strongholds of the Bohemian Kingdom).

Thematically the most substantial group is comprised of books focused on the theory, development and creation of parks and gardens. There are two books describing compositions of parks of the second half of the $19^{\text {th }}$ century, namely, a book by the eminent French garden architect E. André written in French, L'Art des jardins. Trait géneral de la composition des parcs et Jardins (André, 1879) and Lehrbuch der schönen Gartenkunst. Mit besonderer Rücksicht auf die praktische Ausführung von Gärten und Parkanlagen written in German by G. Meyer (1895). The newer books that engage interest include e.g. a number of books by G. Jekyll, C. Schneider, W. Lange, and J. Kumpán.

Dendrological books are of course represented by authors such as C. Schneider and H. E. Wilson, e.g. with his popular book Aristocrats of the Trees (Wilson, 1930) and several others. A book on evergreen woody plants written in Czech by Josef Mišák (Mišák, 1925) is also found here, just as many other, mainly foreign language publications suitable for research purposes in the field of dendrology. The subject of floriculture is nonetheless interestingly covered especially by foreign language publications. Here we find monographs focused on gladiola, carnations, primroses, daylilies, daffodils, colchicums, chrysanthemums and many other genera; literature written both in German and in English devoted to flower gardens but also books focused on flowers for cutting and interior plants. Among foreign authors we find e.g. H. R. Wehrhahn and K. Foerster; Czech authors are represented by J. Těšitel and J. Vaněk.

Although literature dedicated to creating rock gardens and alpine plants is represented by a lower number of books, there is a very high quality 
collection of books of that period by authors such as E. Wocke and R. Farrer, being new editions of books that were already in possession of A. E. Silva Tarouca. Among other authors T. W. Sanders, H. Correvon, or C. R. Jelitto can be named.

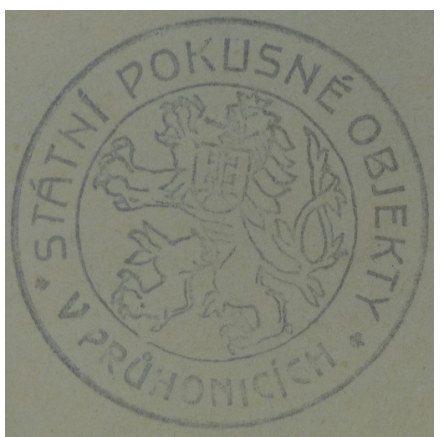

4: Stamp of the State Agricultural Experimental Objects
There are no more books with dedications in the library of the State Experimental Objects. Some books are provided with notes whose author may have been the director of the Experimental Objects, Assoc. Prof. B. Kavka.

\section{Overall Evaluation}

It is evident from the overall summary (Tab. I) in which time periods books were purchased into which stocks. Purchases were mainly associated with the founding of a society or institution; at the same time, it is visible that often books of an older date were purchased, a fact which can be distinguished due to the marking of the book by the appropriate stamp. Books from the end of the $18^{\text {th }}$ century have been preserved in the minimum number of only two titles, one of which was purchased by the State Experimental Objects as late

I: Classification of the entire library stock until 1936 based on the originator and time of edition, excluding price lists and periodicals

\begin{tabular}{ccccccc}
\hline \multicolumn{7}{c}{ Origin of books } \\
\hline Time of edition & $\begin{array}{c}\text { Albert Graf } \\
\text { Nostitz }\end{array}$ & $\begin{array}{c}\text { Dendrological } \\
\text { Society }\end{array}$ & $\begin{array}{c}\text { A. E. Silva } \\
\text { Tarouca }\end{array}$ & $\begin{array}{c}\text { State Experimental } \\
\text { Orchard in Prühonice }\end{array}$ & $\begin{array}{c}\text { State Experimental } \\
\text { Objects }\end{array}$ & $\begin{array}{c}\text { Total } \\
\text { number }\end{array}$ \\
\hline $1769-1799$ & & & 1 & & 1 & 2 \\
$1800-1849$ & 2 & & 3 & 4 & 31 & 5 \\
$1850-1899$ & 6 & 1 & 34 & 9 & 297 & 37 \\
$1900-1936$ & & 36 & 30 & 13 & 329 & 455 \\
\hline Total number & 8 & 37 & 68 & & & \\
\hline
\end{tabular}

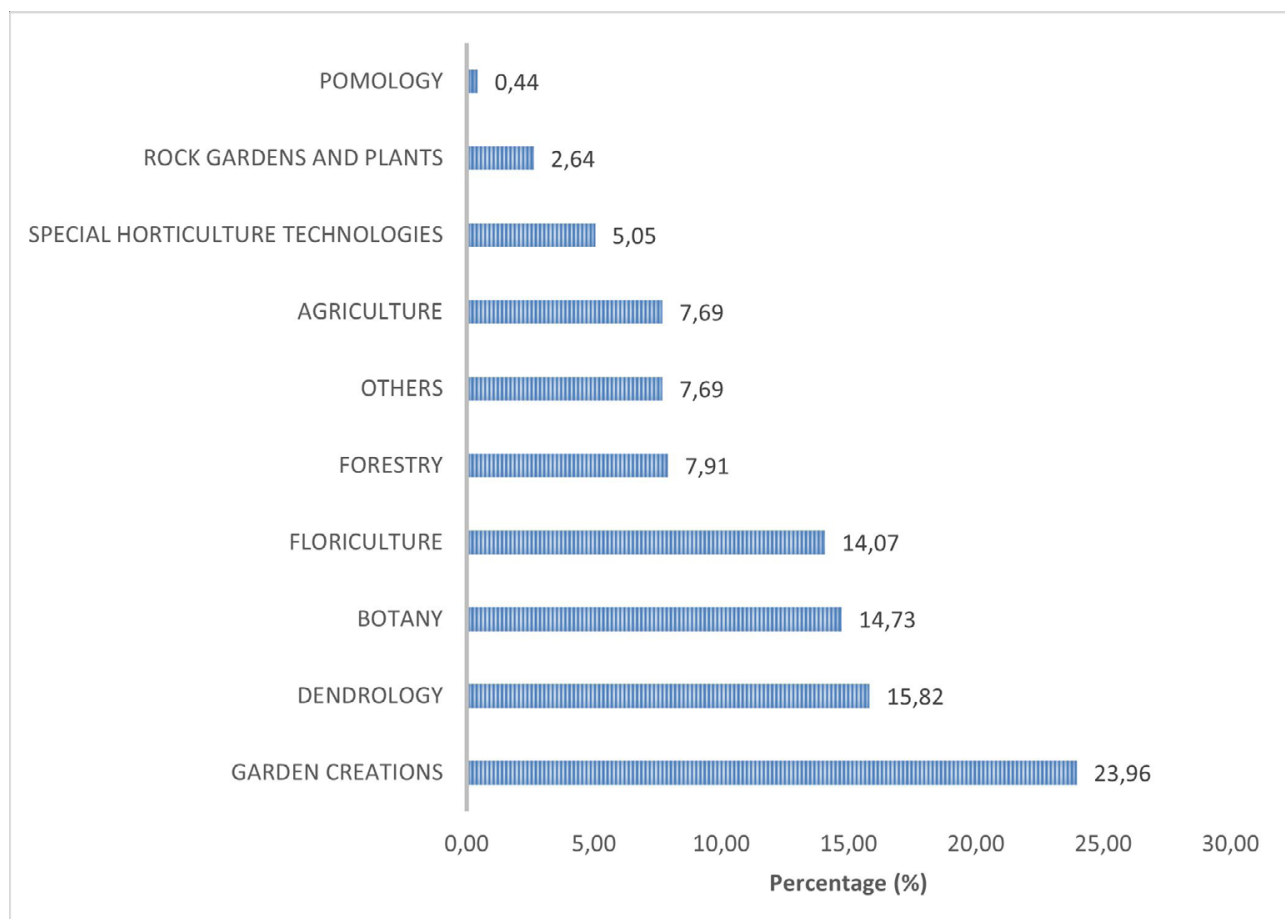

5: Complete library stock with the proportional representation of books according to their thematic focus until the year 1936, excluding price lists and periodicals 
as in 1927. A very small number of books come also from the first half of the $19^{\text {th }}$ century that belonged either to A. E. Silva Tarouca's or the Nostitz library. Books from the end of the $19^{\text {th }}$ century are those that were largely purchased by A. E. Silva Tarouca or the State Agricultural Experimental Objects. The largest number of books come from the period after 1900 until the year 1936 when the State Agricultural Experimental Objects were making most purchases.

In order to summarize, we processed and evaluated the topics that the whole preserved library stock was devoted to (Fig. 5). The most substantial is the subject of garden creations, almost equally represented are categories of floriculture, dendrology, and botany. After a gap, there are again equally represented books that focus on agriculture, forestry, and other books. Markedly fewer books are represented in the category dedicated to other horticulture technologies and pomology. Alpine plants were singled out as a separate category even though they comprise only 12 books, however, they were important within the context of the time period.

\section{DISCUSSION}

Compared to other analyses of chateau libraries (Ševčíková, 2018; Antonín, 1997, 1999), the studied collection contains many more books from the second half of the $19^{\text {th }}$ century and the first half of the $20^{\text {th }}$ century. This is due to the manner in which the library was built which was started systematically by A. E. Silva Tarouca in 1885 after he took over the Průhonice estate and started building the local park (Pincová, 2005). In comparison to other chateau libraries, the horticultural literature stock from the end of the $19^{\text {th }}$ and the beginning of the $20^{\text {th }}$ century is overly abundant (Pražmová, 2010; Mašek, 2018). The studied book collection is not comparable with specialized stocks in the Czech Republic (e.g. Library of the Faculty of Horticulture of the Mendel University, Agricultural Library of the Ministry of Agriculture) and abroad (e.g. Hennebo Collection in the Leibniz University Library in Hannover, Library of the University of Natural Resources and Life Sciences in Vienna, Dumbarton Oaks Research Library and Collection in Washington) in its extent because it contains only 619 items. On the other hand, it represents specific collection that was created in one place and under the influence of one person, A. E. Silva Tarouca.

A. E. Silva Tarouca's library and the libraries of the subsequent institutions have succeeded to concentrate the best of literature that was available in Bohemia and Europe up to the year 1936. As A. E. Silva Tarouca associated with many specialists some of which were even his peers, he was able to stand at the beginnings of many major undertakings in ornamental horticulture. Yet, it cannot be claimed that it is a complete or exhaustive collection of the literature available at the time. Of the commonly available books that could be found in Czech libraries until the end of the $19^{\text {th }}$ century which are mentioned by Nožička (1965, 1966), only two volumes appear, namely, André (1879) and the very common Pückler-Muskau (1834). However, the stock contains many other interesting titles. The fact that the collection was made selectively could be illustrated also by the journals. In the library we find the important Czech magazine edited by Fr. Thomayer and M. Fulín Casopis českých zahradníků (Czech Gardeners' Magazine) with rich colored illustrations, furthermore, České zahradnické listy (Czech Horticultural Notes), later Československé zahradnické listy (Czechoslovak Horticultural Notes) and many others. However, there is a lack of periodicals such as Pražská zahradnická bursa (Prague Gardening Swap), Zahrada domácí a školní (Home and School Garden), Český zahradník (Czech Gardener), Pokrokové zahradnické listy (Modern Gardening Notes), Zahradnický věstník (Gardening Bulletin) etc. Thus, it cannot be claimed that the library is an exhaustive collection but one striving to subscribe to and purchase up-to-date high quality literature, both Czech and foreign. For example, there are valuable foreign books describing the gardens of England and Germany of the beginning of the $20^{\text {th }}$ century.

For the building of A. E. Silva Tarouca's library it is important that the Tarouca family library was deposited in the chateau in Čechy pod Kosírem which was inherited and managed by his older brother František Josef II (Šrek, 2018). Surprisingly, in the library in Čechy pod Kosířem very few books are found that are focused on horticultural topics, although it is very probable that it once contained more of them because books from the chateau library were moved and sold frequently in the past. The current stock lacks the otherwise common scientific works from various fields. Sporadically, A. E. Silva Tarouca's books are also found in the library in Čechy pod Kosířem (Mašek, 2018).

Likewise, we can differentiate between the focus of A. E. Silva Tarouca's library, who predominantly collected books complementing his personal interests, meanwhile the collection within the library of the Dendrological Society and the Experimental Objects is more focused on completing up-to-date high quality horticultural literature, yet, many common books of that period are missing there. However, these books were purchased later and to this day, not only current horticultural literature but also important historical books are being added to the collection.

The Czechoslovak Dendrological Society's activity was preceded by the Austro-Hungarian Dendrological Society founded in 1908 by A. E. Silva Tarouca, Camillo Schneider and Earl Istvan Ambrozy-Migazzi. The Dendrological Society united specialists, published books and supported the introduction of plants. For these activities a specialized library was needed which the society owned. We know only very little about its creation 
and book stock. According to Schneider's report (Schneider, 1920), after the disorganization of the Austro-Hungarian Dendrological Society in 1918 the library including its collection of photographs was passed on to the Österreichische GartenbauGesellschaft which was supposed to fill in for the landscaping section of the ending Austro-Hungarian Dendrological Society. However, due to the frequent moving of the Österreichische GartenbauGesellschaft, the stock has not been preserved. The Österreichische Gartenbau-Gesellschaft still operates to this day, now being located in the building of the Österreichisches Gartenbaumuseum and the Kagran Horticulture School in Vienna. Thanks to the cooperation with its library, we have been able to locate three books in it with a stamp of the Austro-Hungarian Dendrological Society. These books were Vilmorin's illustrierte Blumengärtnere
(Grönland and Rümpler, 1873), an iris monograph written in English from 1913 (Dykes, 1913), and a richly illustrated rose monograph from 1912 (Amat, 1912) with a dedication to the library of the Austro-Hungarian Dendrological Society from Maurice L. de Vilmorin, president of the rose section within the French Horticultural Society (Société nationale d'horticulture de France). The same book with a nominal dedication by M. L. de Vilmorin was received as a personal edition by Earl A. E. Silva Tarouca; the book is nowadays deposited in the library of the Research Institute for Landscape and Ornamental Gardening. At present, the library of the Österreichische Gartenbau-Gesellschaft is being re-catalogued, and it is therefore possible that more books belonging to the former Austro-Hungarian Dendrological Society will be found.

\section{CONCLUSION}

To summarize the issue of the book stock of A. E. Silva Tarouca, the Czechoslovak Dendrological Society and the State Experimental Agricultural Objects, we can say that it is a very important aggregate of books with a horticultural subject matter with a focal point in the period from the end of the $19^{\text {th }}$ century until the 1930s. Due to the cooperation between the leading figure of Earl A. E. Silva Tarouca and the active members of the Czechoslovak Dendrological Society and later the employees of the State Agricultural Experimental Objects under the leadership of Assoc. Prof. B. Kavka, to this day a collection has been preserved of the most important books on gardens that were published in Europe and on our territory at the beginning of the $20^{\text {th }}$ century. Besides books we need to mention also the almanacs of major horticulture societies and a collection of gardening magazines written in Czech and German. It thus provides an overview of the most important events that took place in the horticultural literature over more than three decades in our country as well as in Europe. In this sense, the library becomes a very good base for studying the history of the field in the mentioned time period. At the same time, a large part of literature has been preserved, including mainly A. E. Silva Tarouca's books, that were used as an inspiration for the creation of the Pruhonice park. It thus completes the image of one of the important time periods of the art of gardening.

All the books of these stocks are deposited in the library of the Research Institute for Landscape and Ornamental Gardening in Průhonice. This collection is not scanned but could be studied in the library or borrowed by interlibrary loan services.

\section{Acknowledgements}

This research was funded by the Ministry of Culture of the Czech Republic (NAKI II) DG16P02M027 Průhonice as a horticultural phenomenon - more than 100 years of introduction, breeding and use of ornamental herbaceous plants.

Special thanks are due to the librarians at the Silva Tarouca Research Institute for Landscape and Ornamental Gardening, especially to Jana Dostálková and Eva Obdržálková.

\section{REFERENCES}

ANTONÍN, L. 1997. Drobná zahradní architektura v předlohových knihách zámeckých knihoven. In: Kamenná kniha. Sborník k romantickému historismu - novogotice. Sychrov: Zámek Sychrov, pp. 236-241. ANTONíN, L. 1999. Příspěvky k ikonografii zámeckých zahrad a lázeňských parků ze zámeckých knihoven. Zprávy památkové péče, 59(7): 221-226.

AMAT, C. 1912. Les plus belles roses au début du XX siécle. Paris: Charles Amat.

ANDRÉ, E. 1879. L'Art des jardins. Trait géneral de la composition des parcs et jardins. Paris: G. Mason. BAROŠOVÁ, I., VÁVROVÁ, V., ŠANTRŮČKOVÁ, M. 2017. Činnost Československé dendrologické společnosti v kontextu zahradní tvorby první republiky (1918-1938). In: Zahradní architektura první poloviny 20. století. Praha: Národní zemědělské muzeum, pp. 8-21. 
BATĚK, L., KUMPÁN, J. 1922. Zakládání a vysazování zahrad okrasných. Praha: Československé zahradnické listy.

BOSSE, J. W. F. 1859. Handbuch der Blumengärtnerei. I-III. Hannover: Hahn'sche Hofbuchhandlung. COLOMELLA, L. J. M. 1769. Zwölf Bücher von der Landwirtschaft. Hamburg: Cramer.

COMMISSION DES PRIVILEGIRTEN INDUSTRIECOMTOIRS. 1797. Sammlunng in- und ausländischer Holzarten zur technologischen Kenntniss, Charakteristik und Waarenkunde aller Kunst-, Farb- und Apothekerholzer 1. Gotha: Expedition der Handlungszeitung - Commission des privilegirten Industriecomtoirs.

DOMIN, K. 1928. Introductory Remarks to the fifth international phytogeographic excursion through Czechoslovakia. Acta Botanica Bohemica, 6-7: 3-76.

DYKES, W. R. 1913. The Genus Iris. Cambridge: University press.

EFFENBERGER, F. F. 1828. Felsen - Pantheon und Natur - Park auf der Herrschaft Kleinskal in Böhmen. Leitmeritz: C.W.Medau.

FOERSTER, K., SCHNEIDER, C. 1927. Dahlienbuch. Berlin-Westend: Verlag der Gartenschönheit.

GRÖNLAND, J., RÜMPLER, C. 1873. Vilmorin's ilustrirte Blumengärtnerei. Berlin: Wiegandt, Hempel \& Parey.

HARTWIG, J. 1892. Illustriertes Gehölzbuch. Die schönsten Arten der in Deutschland winterharten oder doch leicht zu schützenden Bäume und Sträucher, ihre Anzucht, Pflege und Verwendung. Berlin: Parey.

HIS MAJESTY'S STATIONERY OFFICE. 1921. Notes From the Royal Botanic Garden. 1919-1921. Edinburgh: His Majesty‘s Stationery Office.

HIS MAJESTY'S STATIONERY OFFICE. 1928. Notes From the Royal Botanic Garden. 1928. Edinburgh: His Majesty's Stationery Office.

HLUBEK, F. X. 1839. Die Runkelrübe, ihr Anbau und die Gewinnung des Zuckers. Laibach: Ignaz Aloys Edlen von Kleinmayr.

JÄGER, H. 1873. Die schönsten Pflanzen des Blumen- und Landschaftsgartens, der Setvächshäuser und Wohnungen. Ein vollständiges Blumenlexikon. Hannover: Cohen u. Risch.

JÄGER, H. 1881. Die neuen schönsten Pflanzen des Blumen- und Landschaftsgartens, der Gewächshäuser und Wohnungen. Supplement zum vollständigen Blumenlexikon. Hannover: Cohen.

JÄGER, H. 1888. Gartenkunst und Gärten sonst und jetzt. Handbuch für Gärtner, Architekten und Liebhaber mit 245 Abbildungen. Berlin: Paul Parey.

JÄGER, H., BEISSNER, L. 1889. Die Ziergehölze der Gärten und Parkanlagen. Beschreibung, Kultur und Verwendung allaer bis jetzt näher bekannten Holzpflanzen und ihrer Abarten, welche in Deutschland und Ländern von gleichem Klima im Freien gezogen werden können. Weimar: Voigt.

J. LORENZ. 1894. Vzorný sběratel př́rodnin. Návod ku zakládání sbírek prírodních ku chytání a upravování motýlů, brouků a jiných živočichů, jakož i ku zřizováni akvárií a terárií. Třebíč: J. Lorenz.

LANGE, W. 1913. Der Garten und seine Bepflanzung. Stuttgart: Kosmos.

LANGE, W., STAHN, O. 1919. Gartengestaltung der Neuzeit. Leipzig: Weber.

LAUCHE, W. 1883. Deutsche Dendrologie. Systematische Uebersicht, Beschreibung, Kulturanweisung und Verwendung der in Deutschland ohne oder mit Decke aushaltenden Bäume und Sträucher. Berlin: Parey.

LENZ, H. O. 1874. Die Schwämme. Gotha: Thieman's Hofbuchhandlung.

LIGUSTICA, A. 1898. Riviera nature notes. Manchester: Labour Press Ltd.

MAREČEK, J. 2018. Tradice výzkumu zahradnictví a zahradní a krajinářské architektury v Průhonicích-její poctivé budování, bezohledné a hrubé zašlapání a nové vzkř́íeni s nadějí lepších časů (1927-1962-19711991 a další léta). Průhonice: VÚKOZ, v.v.i.

MAŠEK, P. 1991. Příspěvky k dějinám zámeckých knihoven západních Čech (Chodová Planá, Lázeň, Merklín, Poběžovice, Zelená Hora). Sborník archivních prací, 41(2): 511-536.

MAŠEK, P. 1993. Zámecká knihovna Bečov. Miscellanea Oddělení rukopisů a starých tisků, 10(2): 475-489.

MAŠEK, P. 2003. Knihovny hrabat Czerninů z Chudenic. In: K výzkumu zámeckých, měštanských a církevních knihoven. Čtenár a jeho knihovna. Opera romanica 4. České Budějovice: Jihočeská univerzita v Českých Budějovicích, pp. 239-253.

MAŠEK, P. 2018. Zámecká knihovna Čechy pod Kosířem. Zprávy Vlastivědného muzea v Olomouci, 316: 33-42.

MEYER, G. 1895. Lehrbuch der schönen Gartenkunst. Mit besonderer Rücksicht auf die praktische Ausführung von Gärten und Parkanlagen. Berlin: Wilhelm Ernst \& Sohn.

MINISTERIUM DER GEISTLICHEN, UNTERRICHTS- UND MEDIZINAL-ANGELEGENHEITEN. 1909. Der Königliche Botanische Garten und das Königliche Botanische Museum zu Dahlem. Berlin: Ministerium der Geistlichen, Unterrichts- und Medizinal-Angelegenheiten.

MIŠÁK, J. 1925. Vždy zelené stromoví listnaté. Zkušenosti, v Mlyňanech nabyté podává Josef Mišák. Berlin-Westend: Verlag der Gartenschönheit.

MÜTZE, W., SCHNEIDER, C. 1924. Das Rosenbuch. Berlin-Westend: Verlag der Gartenschönheit. 
NOŽIČKA, J. 1965. Počátky a vývoj okrasně zahradnické a sadovnické literatury u nás. In: Vědecké práce Výzkumného ústavu okrasného zahradnictví v Průhonicích 3. Praha: Státní zemědělské nakladatelství, pp. 155-165.

NOŽIČKA, J. 1966. Přehled vývoje okrasného zahradnictví a sadovnictví v českých zemích. In: Vědecké práce Československého zemědělského muzea 5. Praha: Státní zemědělské nakladatelství, pp. 7-75.

PETZOLD, E. 1888. Die Landschafts-Gärtnerei. Ein Handbuch für Gärtner, Architekten und Freunde der Gartenkunst. Leipzig: Haessel.

PINCOVÁ, V. 2005. Průhonické panství a park v proměnách století a majitelů. In: Historické zahrady a parky. Průhonice dř́ve a nyní. Odborný seminář 16.-17. 6. 2005. Průhonice: Botanický ústav AV ČR - Výzkumný ústav Silva Taroucy pro krajinu a okrasné zahradnictví - Agentura Bonus, pp. 1-13.

PRAŽMOVÁ, I. 2010. Zahradnická literatura v zámeckých knihovnách České republiky. Bakalářská práce. Lednice na Moravě: Zahradnická fakulta Mendelovy univerzity v Brně.

PÜCKLER-MUSKAU, H. 1834. Andeutungen für Landschaftsgärtnerei. Stuttgart: Hallberger'sche Verlagshandlung.

PÜCKLER-MUSKAU, H. 1834. Andeutungen über Landschaftsgärtnerei verbunden mit der Beschreibung ihrer praktischen Anwendung in Muskau. Leipzig: Hans Friedrich.

RÜMPLER, T. 1882. Die schönblühenden Zwiebelgewächse, ihre Kultur im Garten, Gewächshaus und Zimmer. Berlin: Parey.

SARGENT, C. S. 1913-1914. Plantae Wilsonianae an Enumeration of the Woody Plants Collected in Western China for the Arnold Arboretum of Harvard University During the Years 1907, 1908 and 1910 by E. H. Wilson Band I-IV. Cambridge: Arnold Arboretum, Publications of the Arnold Arboretum 4.

SCHELLE, E. 1909. Die winterharten Nadelhölzer Mitteleuropas. Stuttgart: Ulmer.

SCHNEIDER, C. 1904. Deutsche Gartengestaltung und Kunst. Leipzig: Scholzes.

SCHNEIDER, C. 1907. Landschaftliche Gartengestaltung. Leipzig: Carl Scholze.

SCHNEIDER, C. 1920. Aus den Vereinen. Zeitschrift für Garten und Obstbau, Organ der Österrechischen Gartenbau-Gesellschaft, 1(4): 46.

SILVA-TAROUCA, A. E., SCHNEIDER, C. et al. 1927. Unsere Freiland-Stauden. Pflege und Verwendung aller Bekannten in Mitteleuropa im freien kulturfähigen ausdauernden krautigen Gewächse. $4^{\text {th }}$ Edition. Wien-Leipzig: Hölder-Pichler-Tempsky.

ŠEVČÍKOVÁ, B. 2018. Analysis of the castle library as a source of new infomation on the development of the garden in Vlašim. Acta Universitatis Agriculturae et Silviculturae Mendelianae Brunensis, 66(5): 1207-1215.

ŠREK, R. 2018. František Josef II. Silva Tarouca (1858-1936). Zprávy Vlastivědného muzea v Olomouci, 316: 150-161.

VOS, G., SANDERS T. W. 1902. Easily-grown Hardy perennials. London: W. H. and L. Collingridge.

WILSON, H. E. 1930. Aristocrats of the Trees. Boston: Stratford Company.

Contact information

Ivana Barošová: barosova@vukoz.cz (corresponding author)

Markéta Šantrůčková: santruckova@vukoz.cz 
